\title{
02 Agricultural development and policy before and after China's WTO accession
}

\section{Jikun Huang and Scott Rozelle}

China's economy has experienced remarkable growth and significant structural changes since economic reforms were initiated in 1979. The annual average growth rate of gross domestic product (GDP) has been about 9 per cent in the past three decades (NBSC 2006). This rapid growth has been accompanied by a significant structural shift in the economy from agriculture to industry and services.

Although agriculture's share of the economy has been falling, China has still enjoyed agricultural growth rates that have considerably outpaced the increase in population. Food security-one of the issues of central concern to policymakers in China-has also improved significantly since the late 1970s. Contrary to the predictions of many analysts that China would put pressure on global food security in the course of its rapid industrialisation and the liberalisation of its economy, large net food import growth has not occurred (Huang et. al 2007). At the micro level, China has made remarkable progress in improving household food security and reducing the incidence of malnutrition during the past two and half decades.

While past accomplishments are impressive, there are still great challenges ahead. For example, income disparity has risen along with rapid economic growth. There are significant income disparities among regions, between urban and rural regions and households, and among households within the same location (Cai et al. 2002; World Bank 2002). Within the 
agricultural sector, China is also facing increasing challenges due to the diminishing amount of cultivated land in eastern China and increasing water scarcity in the northern part of the country (Sonntag et al. 2005). Many have predicted that almost all gains in agricultural output will have to come from new technologies that significantly improve agricultural productivity (Fan and Pardey 1997; Huang et al. 2002, 2003).

Trade liberalisation might also challenge China's agricultural and rural economy. There have been serious debates about the impact of World Trade Organization (WTO) accession on China's agriculture. Some argue that there will be substantial adverse impacts from trade liberalisation, affecting hundreds of millions of farmers (Carter and Estrin 2001; Li et al. 1999). Others believe that although some impacts will be negative and even severe in particular areas, the overall effect of accession on agriculture will be modest (Anderson et al. 2004; van Tongeren and Huang 2004; Martin 2002). In part, the differences in opinion can be traced to a lack of understanding of the policy changes that occurred before China's accession.

The objective of this chapter is to review China's agricultural development and policy before and since WTO accession. The chapter is organised as follows: first, we briefly review China's agricultural performance and policies before accession to the WTO. Next, we examine the main features of the agreement that China must adhere to as it enters the WTO. Third, we review changes in China's agricultural policy since joining the WTO. Finally, we conclude by drawing out the implications of the policy changes.

\section{Agricultural performance and policy before China's WTO accession}

Agricultural performance

China's economic liberalisation and structural changes have been under way for several decades. Although the reforms have penetrated the whole economy since the early 1980s, most of the transformations began and in some way have depended on growth in the agricultural sector (Nyberg and Rozelle 1999). In the period from 1978 to 1984, de-collectivisation, price increases and the relaxation of local trade restrictions on most agricultural products accompanied a take-off of China's agricultural economy. Grain 
output has increased by 4.7 per cent per annum, and there has been even higher growth in horticultural, livestock and aquatic products (Table 2.1). Although agricultural growth decelerated after 1985-following the one-off efficiency gains from de-collectivisation-the country still enjoyed agricultural growth rates that outpaced the increase in population (Table 2.1).

Despite the healthy increase in agricultural output, the even faster growth of the industrial and services sectors during the reform era has begun to transform the rural economy-from agriculture to industry and from rural to urban. During this process, the share of agriculture in the national economy has declined significantly. Whereas agriculture contributed more than 30 per cent of GDP before 1980, its share fell to 16 per cent in 2000 and to less than 13 per cent in 2005. Meanwhile, the share of services rose from 13 per cent in 1970 to 40 per cent in 2005 (Table 2.2).

Rapid economic growth and urbanisation have boosted demand for meats, fruits and other non-staple foods-changes that have stimulated sharp shifts in the structure of agriculture (Huang and Bouis 1996). For example, the share of livestock's output value in agriculture more than doubled from 14 per cent in 1970 to 30 per cent in 2000 (Table 2.2). Aquatic products rose at an even more rapid rate. One of the most significant signs of structural change in the agricultural sector is that the share of crops in total agricultural output fell from 82 per cent in 1970 to 56 per cent in 2000, and it has continued to fall since China's WTO accession in 2001. Moreover, the most significant declines in crop growth rates have been experienced in the grain sector (Table 2.1).

Changes in the external economy for agricultural commodities have paralleled those in domestic markets. Whereas the share of primary (mainly agricultural) products in total exports was more than 50 per cent in 1980, it fell to less than 10 per cent in 2000 (NBSC 1980-2000). In the same period, the share of food exports in total exports fell from 17 per cent to 5 per cent. The share of food imports also fell sharply-from 15 per cent to 2 per cent.

Crop-specific trade trends show equally sharp shifts and suggest that exports are moving increasingly towards products in which China has a comparative advantage (Huang et al. 2007). The net exports of land-intensive bulk commodities such as grains, cotton, oil seeds and sugar crops have fallen; exports of higher-valued, more labour-intensive products, such as horticultural and animal (including aquaculture) products, have risen (Figure 2.1). 
Table 2.1 Annual growth rates of China's economy, 1970-2004 (per cent)

\begin{tabular}{|c|c|c|c|c|c|}
\hline & \multirow{2}{*}{$\begin{array}{c}\text { Pre-reform } \\
1970-78\end{array}$} & \multicolumn{4}{|c|}{ Reform period } \\
\hline & & $1979-84$ & 1985-95 & $1996-2000$ & 2001-04 \\
\hline Gross domestic product & 4.9 & 8.8 & 9.7 & 8.2 & 8.7 \\
\hline Agriculture & 2.7 & 7.1 & 4.0 & 3.4 & 3.4 \\
\hline Industry & 6.8 & 8.2 & 12.8 & 9.6 & 10.6 \\
\hline Services & n.a. & 11.6 & 9.7 & 8.3 & 8.3 \\
\hline Population & 1.80 & 1.40 & 1.37 & 0.91 & 0.63 \\
\hline Per capita GDP & 3.1 & 7.4 & 8.3 & 7.2 & 8.1 \\
\hline Grain production & 2.8 & 4.7 & 1.7 & 0.03 & -0.2 \\
\hline \multicolumn{6}{|l|}{ Rice: } \\
\hline Production & 2.5 & 4.5 & 0.6 & 0.3 & -0.9 \\
\hline Area & 0.7 & -0.6 & -0.6 & -0.5 & -1.2 \\
\hline Yield & 1.8 & 5.1 & 1.2 & 0.8 & 0.2 \\
\hline \multicolumn{6}{|l|}{ Wheat: } \\
\hline Production & 7.0 & 8.3 & 1.9 & -0.4 & -1.9 \\
\hline Area & 1.7 & 0.0 & 0.1 & -1.4 & -5.1 \\
\hline Yield & 5.2 & 8.3 & 1.8 & 1.0 & 3.3 \\
\hline \multicolumn{6}{|l|}{ Maize: } \\
\hline Production & 7.4 & 3.7 & 4.7 & -0.1 & 5.5 \\
\hline Area & 3.1 & -1.6 & 1.7 & 0.8 & 2.5 \\
\hline Yield & 4.2 & 5.4 & 2.9 & -0.9 & 2.8 \\
\hline \multicolumn{6}{|l|}{ Other production } \\
\hline Cotton & -0.4 & 19.3 & -0.3 & -1.9 & 6.5 \\
\hline Soybean & -2.3 & 5.2 & 2.8 & 2.6 & 2.4 \\
\hline Oil crops & 2.1 & 14.9 & 4.4 & 5.6 & 0.6 \\
\hline Fruits & 6.6 & 7.2 & 12.7 & 8.6 & 29.5 \\
\hline \multicolumn{6}{|l|}{ Meats (pork/beef/ } \\
\hline poultry) & 4.4 & 9.1 & 8.8 & 6.5 & 4.6 \\
\hline Fish & 5.0 & 7.9 & 13.7 & 10.2 & 3.5 \\
\hline \multicolumn{6}{|l|}{ Planted area: } \\
\hline Vegetables & 2.4 & 5.4 & 6.8 & 6.8 & 3.8 \\
\hline Orchards (fruits) & 8.1 & 4.5 & 10.4 & 1.5 & 2.2 \\
\hline
\end{tabular}

Note: Figures for GDP for 1970-78 are the growth rates of national income in real terms. Growth rates were computed using regression analysis. Growth rates for individual commodities and groups of commodities are based on production data.

Sources: National Bureau of Statistics of China, various issues (1985-2005). China Statistical Yearbook, China Statistics Press, Beijing; Ministry of Agriculture, 1985-2005 (various issues). China's Agricultural Yearbook, China Agricultural Press, Beijing. 
Table 2.2 Changes in the structure of China's economy, 1970-2005 (per cent)

\begin{tabular}{lccccccc}
\hline & 1970 & 1980 & 1985 & 1990 & 1995 & 2000 & 2005 \\
Share of GDP & & & & & & & \\
Agriculture & 40 & 30 & 28 & 27 & 20 & 16 & 13 \\
$\begin{array}{l}\text { Industry } \\
\text { Services }\end{array}$ & 46 & 49 & 43 & 42 & 49 & 51 & 47 \\
Share of agricultural output & 13 & 21 & 29 & 31 & 31 & 33 & 40 \\
Crops & 82 & 80 & 76 & 65 & 58 & 56 & 51 \\
Livestock & 14 & 18 & 22 & 26 & 30 & 30 & 35 \\
Fisheries & 2 & 2 & 3 & 5 & 8 & 11 & 10 \\
Forestry & 2 & 4 & 5 & 4 & 3 & 4 & 4 \\
& & & & & & & \\
\hline
\end{tabular}

Source: National Bureau of Statistics of China, various issues. China Statistical Yearbook, China Statistics Press, Beijing; National Bureau of Statistics of China, various issues. China Rural Statistical Yearbook, China Statistics Press, Beijing.

Figure 2.1 Agricultural trade balance by factor intensity, 1985-97 (US\$ million)

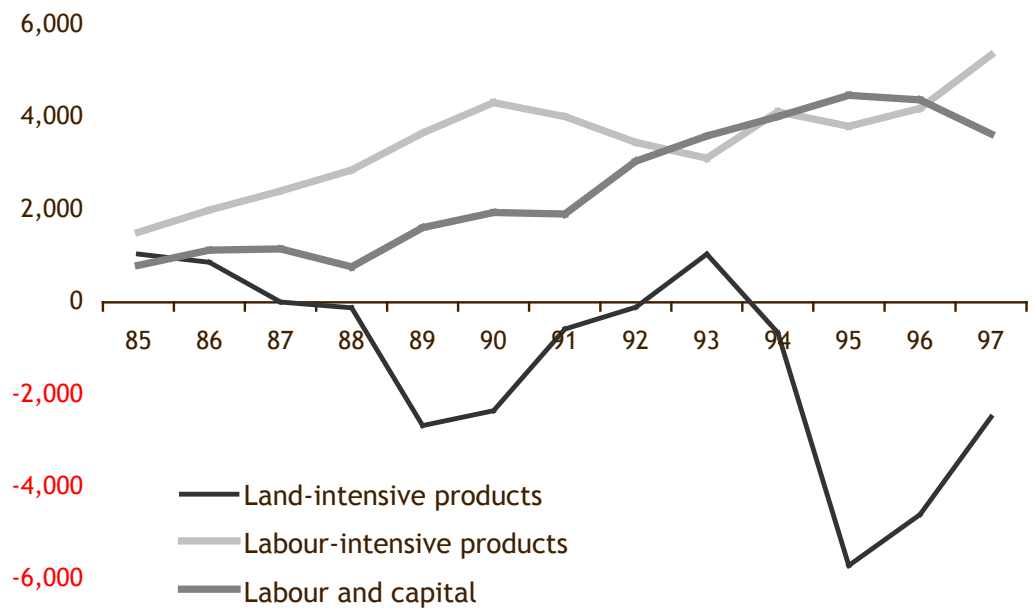

Source: Huang, J. and Chen, C., 1999. Effects of Trade Liberalization on Agriculture in China: institutional and structural aspects, United Nations ESCAP CGPRT Centre, Bogor. 
We believe that, taken as a whole, the trends in China's economic structure and agricultural trade in the two decades before WTO accession reveal that the changes that are being experienced as a result of accession are not new. China was already moving in a direction that was more consistent with its resource endowments. To the extent that the new trade agreements reduce barriers to allow more land-intensive products into the domestic market and the reductions in import restrictions overseas stimulate the export of labour-intensive crops, the main impact of WTO accession is to push forward trends that were already under way. The commitments that China undertook in its WTO Protocol of Accession are largely consistent with the nation's long-term reform plans.

Agricultural development policies

Despite the continuity with the past, few can dispute that the terms of China's WTO accession agreement pose new challenges to the agricultural sector. In some cases, there could be large impacts on rural households and these will undoubtedly elicit a sharp response. While the nature and severity of the impacts will depend on how households respond, perhaps of even greater importance is how China's agricultural policymakers manage their sector as the new trade regime takes effect. To examine this set of issues more carefully, in this section we review agricultural policy before China's WTO accession and in the next section we examine how WTO measures change the policy environment in rural China.

Fiscal and financial policies. While government expenditure in most areas of agriculture increased gradually during the reform period, the ratio of agricultural investment to agricultural gross domestic product (AGDP) declined monotonically from the late 1970s to the mid 1990s. In 1978, the AGDP was 7.6 per cent; by 1995, it had fallen to 3.6 per cent (NBSC 2001). Moreover, a significant outflow of capital from the agricultural sector to the industrial sector and from the rural sector to the urban sector took place during the 1980s and 1990s through the financial system and government agricultural procurement (Huang et al. 2006; Nyberg and Rozelle 1999). After the mid 1990s, when China was preparing for WTO accession, investment in agriculture was increased significantly. This trend of increasing investment in the agricultural and rural sectors has continued since accession. 
Foreign exchange and trade policies. China's policies governing the external economy have played a highly influential role in shaping the growth and structure of agriculture for many decades. During the entire Socialist Period (1950-78), the over-valuation of China's domestic currency destroyed incentives to export, effectively isolating China from international exporting opportunities (Lardy 1995). The government, however, allowed the real exchange rate to devalue by 400 per cent between 1978 and 1994. Except for recent years, when the exchange rate has experienced a slight appreciation, adjustments in the exchange rate throughout most of the reform period increased export competitiveness and contributed to China's export growth record. This, in turn, has assisted the expansion of the national economy. Perhaps more than anything, China's 'open-door' policy, including its exchange rate policy, has contributed to the rapid growth in the importance of the external economy.

Rural development and labour market policies. The shift of labour from the rural sector to the urban sector lies at the heart of a country's modernisation effort, and China has been experiencing this in primarily two ways: by the absorption of labour into rural firms and by massive movement of labour into cities. Rural industrialisation has played a vital role in generating employment for rural labour, raising agricultural labour productivity and farm incomes. The share of rural enterprises in GDP rose from less than 4 per cent in the 1970s to more than 30 per cent by 1999 . Rural enterprises dominated the export sector throughout the 1990s (NBSC 2001). Perhaps most importantly, rural enterprises employ about 35 per cent of the rural labour that works off the farm. In addition to wage-earning jobs in rural areas, a large and increasing part of the rural labour force-up from 8 per cent in 1990 to 13 per cent in 2000 (de Brauw et al. 2002)-also works in the self-employed sector.

Although China's input markets still had a number of structural imperfections-such as employment priority for local workers, housing shortages and the urban household registration system-labour poured into cities during the 1980s and 1990s and the emergence of labour markets has been transforming the economy (Lin 1991; Lohmar 1999; de Brauw et al. 2002). According to a national survey of 1,200 households, more than 100 million rural workers found employment in the urban sector in the late 1990s (de Brauw et al. 2002). China's labour markets have allowed 
migrant work to become the dominant form of off-farm activity. Young and better-educated workers increasingly dominate this activity. It has expanded fastest in regions that are relatively well off; and has recently begun to draw workers from parts of the population, such as women, who earlier had been excluded. If China continues to change at the pace it did in the 1980s and 1990s, and other provinces experience the changes that have taken place in the richest provinces, China's economy should continue to follow a healthy development path and be well along the road to modernisation.

Improved incentives. China's rural economic reform, initiated in 1979, was founded on the household responsibility system (HRS). The HRS reforms dismantled the communes and contracted agricultural land to households, mostly on the basis of family size and the number of workers in the household. Most importantly, after the HRS reforms, control and income rights belonged to individuals. With the exception of the right to sell their land, farmers became the residual claimants of the outcome of their efforts.

There is little doubt that the changes in incentives resulting from these property rights reforms triggered strong growth in output and productivity. In the most definitive study on the subject, Lin (1992) estimated that China's HRS accounted for 42-46 per cent of the total increase in output during the early reform period (1978-84). Fan (1991) and Huang and Rozelle (1996) found that even after accounting for technological change, institutional change during the late 1970s and early 1980s contributed about 30 per cent of output growth. Other researchers have documented impacts that go beyond increases in output. For example, McMillan et al. (1989) found that the early reforms also raised total factor productivity, accounting for 90 per cent of the increase in output (23 per cent) between 1978 and 1984. Jin et al. (2002) also showed that the reforms had a large impact on productivity, accounting for growth in total factor productivity of more than 7 per cent annually.

Domestic output price and market liberalisation policies. Although early in the reforms China's leaders had no concrete plan to liberalise markets, they did take steps to change the incentives faced by producers that were embodied in the prices they received for their marketed surplus. The important contribution of China's pricing policy was in the timing and breadth of the policy change. The first major price rise occurred in 1979, 
almost at the time reformers were deciding to de-collectivise. Agricultural procurement prices have continued to increase gradually since the 1980s. Studies confirm the strong impact of these price changes on output during the early and late years of transition (Lin 1992; Fan 1991; Huang and Rozelle 1996; Fan and Pardey 1997).

In addition to pricing changes and de-collectivisation, another major task of reformers after the mid 1980s was to create more efficient institutions of exchange. Markets-whether classic competitive ones or some workable substitute-increase efficiency by facilitating transactions among agents to allow specialisation and trade and provide information through the pricing mechanism to producers and consumers about the relative scarcity of resources. After 1985, although the process proceeded in a stop-start manner, market liberalisation began in earnest. Changes in the procurement system, further reductions in restrictions on commodities trading, moves to commercialise the state grain trading system and calls for the expansion of markets in rural and urban areas led to a surge in market-oriented activity. For example, in 1980 , there were only 241,000 private and semi-private trading enterprises registered with the State Markets Bureau; by 1990, there were more than 5.2 million (de Brauw et al. 2002).

Despite its stop-start nature, as the right to private trading was extended to include surplus output of all agricultural products after contractual obligations to the State were fulfilled, the foundations of the state marketing system began to be undermined (Rozelle et al. 2000). Reformers eliminated all planned procurement of agricultural products other than rice, wheat, maize and cotton; government commercial departments could buy and sell only through the market. For grain, improved producer incentives were introduced through reductions in the volume of the compulsory delivery quotas and increases in procurement prices. Even for grain, the share of the compulsory quota procurement reached 29 per cent of output in 1984 but declined to 18 per cent in 1985 and to 13 per cent in 1990. The share of the negotiated procurement at market prices increased from only 3 per cent in 1985 to 6 per cent in 1985 and to 12 per cent in 1990.

Technology and water infrastructure development. Agricultural research in China remains almost completely run by the government. Reflecting the urban bias of food policy, most crop breeding programs have emphasised fine 
grains (rice and wheat). For national food self-sufficiency considerations, higher yields have been the major target of China's research program, except in recent years when quality improvement was introduced into the nation's development plan. Although there have been several private domestic and joint-venture investments in agricultural research and development, policies still discriminate against them. Today, the record of reform of the agricultural technology system is mixed and its impact on technological developments and crop productivity is unclear. Empirical evidence demonstrates that while agricultural technology has played a critical role in China's agricultural productivity growth, the effectiveness of China's agricultural research capabilities has been declining (Jin et al. 2002).

Before the economic reforms, the State's agricultural investment was focused on building dams and canal networks, often with the input of corvée labour from farmers. After the 1970s, greater focus was given to increasing the use of China's massive groundwater resources (Wang et al. 2006). By 2005, China had more tube wells than any country in the world-except possibly India. Although initially this investment was made by local governments with aid from county and provincial water bureaux, by the 1990s the national government was encouraging the shift in ownership that was occurring as pump sets and wells and other irrigation equipment went largely into the hands of farm households (Wang 2000). At the same time, private water markets (whereby farmers pumped water from their own wells and sold it to other farmers in the village) were also encouraged. The main policy initiative in the surface-water sector after the mid 1990s was management reform (with the goal of trying to make water use more efficient).

Trade policy. In addition to important changes in foreign exchange policy (changes that saw the nation's currency depreciate steeply and trading rights become more accessible during the 1980s and 1990s), there have been a number of other fundamental reforms of China's international trading system. Lower tariffs and rising imports and exports of agricultural products began to affect domestic terms of trade in the 1980s. Initially, most of the decline in protection affected commodities that were controlled by single-desk, state traders (Huang and Chen 1999). For many products, competition among non-state foreign trade corporations began 
to stimulate imports and exports (Martin 2002). Although trade in many major agricultural commodities was not liberalised, the moves spurred the export of many agricultural goods. In addition, policy shifts in the 1980s and 1990s also changed the behaviour of state traders, who were allowed to increase imports.

Moves to relax the rights of access to import and export markets were matched by action to reduce the taxes that were being assessed at the border. A new effort began in the early 1990s to reduce the level of formal protection of agriculture. From 1992 to 1998, the simple average agricultural import tariff fell from 42.2 per cent to 23.6 per cent, and by 2001 it had reached 21 per cent (Rosen et al. 2004).

Overall, agricultural sector trade distortions declined in the 20 years before China joined the WTO (Huang et al. 2004). Much of the decline in protection came from decentralising the authority for imports and exports and from relaxing licensing procedures for some crops (for example, moving oil and oil seed imports away from state trading firms), as well as foreign exchange rate changes. Other trade policy changes have reduced the scope of non-tariff barriers (NTBs), relaxed the real tariff rates at the border and increased quotas (Huang and Chen 1999). Despite this real and, in some areas, rapid set of reforms, the control of a set of commodities that leaders consider to be of national strategic importance-including rice, wheat and maize-remains with policymakers to a large extent (Nyberg and Rozelle 1999).

Given the changes made before the country's accession to the WTO, it is not surprising that, while it was a major event in China (and will have an impact on many sectors), in its most basic terms it is a continuation of previous policies. Hence, the commitments embodied in China's WTO accession agreement with respect to the agricultural sector-market access, domestic support and export subsidies-are essentially a continuation of what China was doing in the 1990s.

Summary of China's transition-era agricultural policies. The scope of China's policy efforts during the transition era is impressive. Policy shifts were made in pricing, the organisation of production, marketing, investment, technology and trade. Although the rate of investment has risen during the reform period, China is still under-investing in agriculture 
compared with other countries. Taxes-those that are explicit and those that are implicit in pricing and trade policies-also have fallen. While China has not reached a point during the transition era where it heavily subsidises the agricultural economy in a way that characterises its neighbours in East Asia, it appears, however, to be heading in the direction in which developing countries at a certain point begin to turn from extraction from agriculture to net investment in the sector.

Outside of agriculture, many policies and other factors have affected the sector. Other rural policies-for example, fiscal reform, township and village enterprise emergence and privatisation, and rural governancealmost certainly have a large, albeit indirect, effect on agriculture. Urban employment policies, residency restrictions, exchange rate management and many other policy initiatives also affect agriculture by affecting relative prices in the economy, the access to jobs off the farm and the overall attractiveness of remaining on the farm.

Taken together, these policies have been shown to have a dramatic effect on China's agricultural sector. They have increased the output of food, driven agricultural prices down and improved supplies of nongrain food and raw materials for industry. The mix of policies-pricing, property rights, market liberalisation, investment and trade-has also made producers more efficient; it has freed up labour and other resources that are behind the structural transformation of the economy. The most convincing indicators that agriculture is beginning to play an effective role in the nation's development are that the importance of grain is shrinking inside the cropping sector, the importance of the cropping sector is shrinking inside the agricultural sector and the importance of agriculture is shrinking in the general economy. Rural incomes and productivity have increased; however, much of the increase in welfare is being generated by individuals (and there have been more than $\mathbf{2 0 0}$ million of them) who have been able to escape from grain production and move into high-valued crops, escape from cropping and move into livestock and fisheries production and, most importantly, escape from agriculture (the rural economy) and move into off-farm jobs (in the city). 


\section{China's commitments to WTO accession and provisions related to agriculture}

In their most basic terms, the commitments in the agricultural sector can be classified into three categories: market access, domestic support and export subsidies (Martin 2002; Colby 2001; Rozelle and Huang 2001). The commitments on market accession have lowered tariffs on all agricultural products, increased access to China's markets for foreign producers of some commodities through tariff rate quotas (TRQs) and removed quantitative restrictions on others. In return, China is supposed to gain better access to foreign markets for its agricultural products, as well as a number of other indirect benefits.

Its substantial market-access commitments make China's accession unique among developing countries that have been admitted to the WTO. Overall, agricultural import tariffs (in terms of simple averages) declined from about 21 per cent in 2001 to 17 per cent by 2004. Previously, the simple average agricultural import tariff had been reduced from 42.2 per cent in 1992 to 23.6 per cent in 1998.

With a few exceptions-for example, in the case of several "national strategic products'-most agricultural products have become part of a tariffonly regime. According to this part of the agreement, all non-tariff barriers and licensing and quota processes should be eliminated. For most commodities in this group, effective protection fell substantially after January 2002 (Table 2.3). To the extent that tariffs are binding for some of these commodities, the reductions in tariff rates should stimulate additional imports.

It is important to note, however, that although published tariff rates have fallen on all of these commodities, imports will not necessarily grow. Indeed, China has comparative advantage in many of the commodities in Table 2.3. For example, lower tariffs on horticultural and meat products might impact on only a small part of the domestic market-such as those parts that buy and sell only very high-quality products, such as meats for five-star hotels that cater to foreigners. Although tariffs have fallen for all products, since China exports many commodities at below world market prices, the reductions have not affected producers or traders.

The real challenge for agricultural products with tariff-only protection is, therefore, for commodities such as barley, wine and dairy products. To 
Table 2.3 Import tariff rates on major agricultural products subject to tariff-only protection in China

\begin{tabular}{lrrr}
\hline & Real tariff rates in & Effective as of 1 January \\
& 2001 & 2002 & 2004 \\
Barley & $114(3)^{\mathrm{a}}$ & 3 & 3 \\
Soybean & $3^{\mathrm{b}}$ & 3 & 3 \\
Edible oils & $114(3)^{\mathrm{a}}$ & 9 & 9 \\
Citrus & 40 & 20 & 12 \\
Other fruits & $30-40$ & $13-20$ & $10-13$ \\
Vegetables & $30-50$ & $13-29$ & $10-15$ \\
Beef & 45 & 23.2 & 12 \\
Pork & 20 & 18.4 & 12 \\
Poultry meat & 20 & 18.4 & 10 \\
Dairy products & 50 & $20-37$ & $10-12$ \\
Wine & 65 & 45 & 14 \\
Tobacco & 34 & 28 & 10 \\
& & & \\
\hline
\end{tabular}

a Barley was subject to licence and import quotas; the tariff rate was 3 per cent for imports within the quota and no above-quota barley with the 114 per cent tariff was imported in 2001.

b The tariff rate was as high as 114 per cent before 2000 and lowered to 3 per cent in early 2000.

Source: World Trade Organization, 2001. China's WTO Protocol of Accession, November, World Trade Organization, Geneva.

understand what could happen to some of these products it is instructive to examine the case of soybeans, where producers clearly did not have a comparative advantage. Before 2000, the import tariff for soybeans was as high as 114 per cent, importers required licences and soybean demand was met mostly by local producers. In anticipation of WTO accession, however, tariffs were lowered to 3 per cent in 2000 and import quotas were later phased out. Subsequently, imports surged from 4.32 million metric tonnes (mmt) in 1999 to $14 \mathrm{mmt}$ in 2001 and to more than $20 \mathrm{mmt}$ after 2003. Prices also fell and the nominal protection rate for soybeans declined from 44 per cent in early 2000 to less than 15 per cent in October 2001 (Rozelle and Huang 2001). From this case, it can be seen that when protection rates are reduced from high levels and there is strong demand for the commodity, imports can increase sharply. 
Such behaviour has, however, been constrained for a class of commodities called 'national strategic products'. China's WTO agreement allows the government to manage the trade of rice, wheat, maize, edible oils, sugar, cotton and wool with TRQs. These commodities are covered under special arrangements. As shown in Table 2.4, the in-quota tariff is only 1 per cent for rice, wheat, maize and wool (for sugar it is 20 per cent and for edible oils, 9 per cent). The amount brought in at these tariff levels is, however, strictly restricted. For example, in 2002, the first 8.45 $\mathrm{mmt}$ of wheat came in at a tariff rate of 1 per cent. The in-quota volumes were to grow over a three-year period (2002-04) at annual rates ranging from 4 per cent to 19 per cent. For example, maize TRQ volumes increased from $5.7 \mathrm{mmt}$ in 2002 to $7.2 \mathrm{mmt}$ in 2004 . China does not have to bring in this quantity, but provisions are in place such that there is supposed to be competition in the import market so that if there is demand for the national strategic products at international prices, traders will be able to bring in the commodity up to the TRQ level.

At the same time, there are still ways, theoretically, to import these commodities after the TRQ is filled. Tariffs on out-of-quota sales (that is, more than $7.2 \mathrm{mmt}$ in 2004 for maize) dropped substantially in the first year of accession and fell further between 2002 and 2005. If the international price of maize were to fall more than 65 per cent below China's price after 2004, traders would be allowed to import. During the transition period, however, the tariff rates were so high (for example, 65 per cent for grains and sugar in 2004 and edible oils in 2005) that in 2002-05 they were not binding.

After the first four to five years of accession, other changes will take place. For example, China agreed to phase out its TRQ for edible oils after 2006. State wool-trading monopolies could also be phased out and disappear gradually for most other agricultural products (Table 2.4). Although the China National Cereals, Oil and Foodstuffs Import and Export Company will continue to play an important role in rice, wheat and maize, it will face increasing competition in grains trading from private firms.

In its accession commitments, China made a number of other agreements, some of which are China-specific. First, China must phase out all export subsidies and not introduce any such subsidies on agricultural products in the future. Moreover, despite clearly being a developing country, China's de minimis exemption for product-specific support is equivalent to only 8.5 
Table 2.4 China's market access commitments on farm products subject to tariff rate quotas

\begin{tabular}{|c|c|c|c|c|c|c|c|c|}
\hline & \multicolumn{3}{|c|}{$\begin{array}{l}\text { Import volume }(\mathrm{mmt}) \\
\text { (state trading share, \%) }\end{array}$} & \multirow[t]{3}{*}{$\begin{array}{l}\text { Quota growth } \\
\text { (\% p.a.) }\end{array}$} & \multirow[t]{3}{*}{$\begin{array}{l}\text { In-quota } \\
\text { tariff (\%) }\end{array}$} & \multicolumn{3}{|c|}{$\begin{array}{l}\text { Out-of-quota tariff } \\
\text { (\% as of } 1 \text { January) }\end{array}$} \\
\hline & Real & Quota & Quota & & & 2002 & 2003 & 2004 \\
\hline & 2000 & 2002 & 2004 & & & & & \\
\hline \multirow[t]{2}{*}{ Rice } & 0.24 & 3.76 & 5.32 & 19 & 1 & 74 & 71 & 65 \\
\hline & $(100)^{a}$ & (50) & (50) & & & & & \\
\hline \multirow[t]{2}{*}{ Wheat } & 0.87 & 8.45 & 9.64 & 8 & 1 & 71 & 68 & 65 \\
\hline & (100) & $(90)$ & (90) & & & & & \\
\hline \multirow[t]{2}{*}{ Maize } & 0 & 5.70 & 7.20 & 13 & 1 & 71 & 68 & 65 \\
\hline & (100) & (67) & $(60)$ & & & & & \\
\hline \multirow[t]{2}{*}{ Cotton } & 0.05 & 0.82 & 0.89 & 5 & 1 & 54.4 & 47.2 & 40 \\
\hline & (100) & (33) & (33) & & & & & \\
\hline Wool $^{b}$ & 0.30 & 0.34 & 0.37 & 5 & 1 & 38 & 38 & 38 \\
\hline Sugarc & 0.64 & 1.68 & 1.95 & 8 & 20 & 90 & 72 & 50 \\
\hline
\end{tabular}

a Figures in parentheses are the percentage of non-state trading in the import quota.

${ }^{b}$ Designated trading in 2002-04 and phased out thereafter.

c Phased out quota for state trade.

Source: World Trade Organization, 2001. China's WTO Protocol of Accession, November, World Trade Organization, Geneva; National Bureau of Statistics of China, 2001. China Statistical Yearbook, China Statistics Press, Beijing.

per cent of the total value of production of a basic agricultural product (compared with 10 per cent for other developing countries). Moreover, measures such as investment subsidies for farmers and input subsidies for the poor and other resource-scarce farmers, which are generally available for policymakers to use in other developing countries, are not allowed in China-that is, China must include any such support as part of its aggregate level of support, which should be less than 8.5 per cent of agricultural output value.

Because of its socialist background and the difficulty that the world has had in assessing the scope of the government's intervention in business dealings of all types, China agreed to a series of measures governing the way it deals with the rest of the world in cases of anti-dumping and 
countervailing duties. Put simply, special anti-dumping provisions will remain for 15 years after China's WTO accession. In cases of anti-dumping, China will be subject to a different set of rules that countries can use to prove their dumping allegations. In addition, the methods that countries can use against China to enforce anti-dumping claims will differ from most of the rest of the world. In essence, this set of measures makes it easier for countries to bring, prove and enforce dumping cases against China. It should be noted, however, that although the rules differ from those governing trade among other countries, China will have the same rights in its dealings with other countries-which could help it in some dumping matters when it concerns a partner's export behaviour.

China's WTO commitments and privileges associated with the measures in other parts of the agreement also affect its agriculture. For example, on agricultural chemicals, China has committed to replace quantitative import restrictions on three types of fertilisers (DAP, NPK and urea) by TRQs. Tariffs were cut on accession and further cuts have been phased in since 2005 on almost all industrial products (for example, tractors and pesticides). Furthermore, China has reduced significantly its non-tariff measures and eliminated all quotas, tendering and import licensing on non-farm merchandise since 2005. For textiles and clothing, however, the current 'voluntary' export restraints will not be phased out completely until the end of 2008, meaning that exports might not expand as fast as they would under a less restrictive regime. Substantial commitments to open up services markets in China also have been made.

\section{Policy shifts since China's WTO accession}

While the substantial institutional and marketing reforms implemented in agriculture since the late 1970s can facilitate the response of households to the changes that have arisen with the implementation of WTO accessionand more generally in China's transition to the post-accession regime-China still requires considerable reform to meet its WTO commitments (Martin 2002). In fact, the government has realised for a considerable time that it faces a real challenge. In many instances, officials have taken this challenge as an opportunity to accelerate continuing reforms in international and domestic policies. 
Policy responses to WTO accession have taken two forms. First is the policy response required of China in order for it to keep its commitments and to adjust its domestic policies to be consistent with those promulgated by the WTO's rules. The other is the introduction of measures that are allowed under the new framework that could help to boost China's economy and minimise adverse shocks that arise as a result of the accession. Identifying the two kinds of policy changes is essential in studying how accession affects the ways that policymakers respond.

\section{Legal and legislative changes}

Many of the most important changes that have occurred because of the accession are in legal and legislative areas. China reserved the right to use a transitional period of one year from the date of accession to amend or repeal any institution, regulation, law or legal stipulation in its current economic policies in order to make them consistent with the WTO spirit of non-discrimination and transparency. The government had recognised the need for this and had already begun to rectify legal rules and legislation since the late 1990s.

To provide guidance to ministerial and local government authorities in amending or repealing relevant regulations, laws and policies, the State Council decreed two important regulations in January 2002: Regulations on Formulation Process of Laws and Regulations on Formulation Process of Administrative Laws. Essentially a guide for local governments and ministries, these new regulations were issued with the aim of handing over many government functions to the market and directing the government to take a more regulatory, indirect role in commerce and trade. They try to limit the role of government and emphasise that its role is primarily one of providing social and public services. The regulations also seek to simplify administrative processes and increase the transparency of regulations and policies.

The effort to create and implement this new regulatory framework is widespread. For example, during the last stage of WTO negotiations, each ministry formed a leading group or committee to work on all of the laws and regulations under its jurisdiction. These committees typically comprised decision makers and experts who had the mandate to clean up 
all regulations and prepare proposals for amending or repealing those laws and regulations that were not consistent with the WTO rules and China's commitments to its accession. Local governments had similar committees. Ministries and provincial governments are also working closely under the Standing Committee of the National People's Congress on those laws and regulations to be amended or repealed by the congress.

Several recent experiences involving amending laws and regulations and creating new institutions related to agriculture demonstrate the effectiveness of these committees and China's commitment to its WTO obligations. For example, China's Patent Law-which was issued originally in 1984 and amended in 1992-was amended again on 1 July 2001. Many of the associated regulations were also revised. Moreover, a new set of regulations on plant variety protection (PVP) was put into effect in 1999 when China became the thirty-ninth member country of the International Union for the Protection of New Varieties of Plants (UPOV). Soon after passage of the new regulations, government agencies proposed and implemented detailed regulations facilitating the implementation of PVP. The Ministry of Agriculture and the State Forest Bureau also created a new set of institutions: a series of New Plant Variety Protection Offices. Finally, China's Seed Law was issued in 2000. Hence, the PVP and the Seed Law now protect the rights of new plant varieties. To assist in the implementation of these laws, the government has set up an intellectual property rights (IPR) affairs centre under the Ministry of Science and Technology.

To fulfil its legal obligations related to agriculture, the Ministry of Agriculture has, since 2000, also repealed several regulations that sought to subsidise certain types of enterprises and apply different rules in agricultural input industries to different economic actors. Officials have eliminated the Regulations on the Development of Integrated Agricultural, Industrial and Commercial Enterprises under State Farms (issued in 1983 to assist in the development of state-owned farms) and the Regulations on the Development of Rural Township and Village Owned Enterprises (issued in 1979 to assist collectively owned enterprises). Seed Management Regulations that gave monopoly powers to local seed companies and Pesticide Field Trial Rules that discriminated against foreign companies were abolished. 
Despite these substantial efforts, considerable institutional reforms are still needed. There are a number of laws and rules that treat domestic and foreign companies and individuals differently; these need to be changed to allow China to fulfil its legal obligations under its Protocol of Accession to the WTO. It could be an even greater challenge to build the nation's capacity for effective implementation of the amended and new laws.

\section{Agricultural trade reforms}

Changes in tariff policy are more straightforward and simpler than non-tariff policy reforms. China followed its tariff reduction schedule specified in the protocol on the first day of 2002. The average tariff rate was reduced from 15.3 per cent in 2001 to 12 per cent. For agricultural products, the tariff reduction was from 21 per cent to 15.8 per cent. China has also implemented its three years of transition for progressively liberalising the scope and availability of trading rights for agricultural products, as discussed in the previous section.

Compared with the trend in tariff reduction in the past decade, the tariff changes necessary under China's WTO accession should present relatively few problems. Significant reforms of non-tariff measures are, however, required-particularly state trading. China agreed to and did phase out restrictions on trading rights for all products except those under TRQ trade regimes; here, a more gradual approach to phasing out the state-trading regimes has been adopted (Table 2.4). Three years after accession, the private sector has come to dominate the trade of almost all agricultural products. There are, however, provisions to maintain state involvement in three commodities: wheat, maize and tobacco.

Technical barriers to trade (TBT) and sanitary and phytosanitary (SPS) measures, as well as institutional arrangements to fulfil the agreement on Trade-Related Intellectual Property Rights (TRIPS), are the other important issues that China has to deal with. The agreements on TBT and SPS focus on using internationally accepted standards to govern the use of standards as protectionist devices. This rules-based approach can be valuable in improving policy formulation, but is likely to require investment in strengthening standards-related institutions. Comprehensive adoption of 
these measures should lead to improved policies and, by basing policies on a scientific approach, should lead to a move away from the time-consuming and inefficient approach of resolving these issues on a political basis. China has undoubtedly struggled in its efforts to create a fully transparent and open trade regime with respect to non-tariff barriers.

Domestic market reform and infrastructure development

After more than 20 years of reform, China's agriculture has become much more market oriented (de Brauw et al. 2000). Traders move products around the country with increasing regularity and factor markets adjust more rapidly. By the late 1990s, only grain, cotton and, to some extent, silkworm cocoon and tobacco were subjected to price interventions. Even in these cases, markets-especially those for grain-have become increasingly competitive, integrated and efficient.

Despite the gains in market performance in recent years, WTO accession makes demands on China's domestic agricultural markets. The domestic marketing policy response to the nation's WTO accession was substantial and will continue. Major changes have been aimed at improving the efficiency of market performance and minimising the adverse shocks that could arise from external trade liberalisation. Perhaps more than in any other sector, the full liberalisation of cotton and grain markets in China clearly showed that its leaders have been using this opportunity to develop healthy domestic agricultural markets.

In response to WTO accession, the government has ambitious plans to increase investment in market infrastructure. Leaders see a need to establish an effective national marketing information network. Officials in the Ministry of Agriculture have been attempting to standardise agricultural product quality and promote farm marketing. Some have advocated the creation of agricultural technology associations. Generally, all of these moves are part of an effort by leaders to shift fiscal resources that were once used to support China's costly price subsidisation schemes (including domestic and international trade subsidies) to productivity-enhancing investments and marketing infrastructure improvements. 


\section{Land-use policy}

The policy implications of WTO accession on land use and farm organisations are also being hotly debated. Many concerns have arisen about the ability of China's small farms to compete after trade liberalisation. Although every farm household holds title to land, the average farm size is small (about 0.5 hectares). Leaders are pleased with the equity effects of the nation's distribution of land, as it allays concerns about food security and poverty. Land fragmentation and the extremely small scale of farms will, however, almost certainly in some way constrain the growth of farm labour productivity and hold back farm income growth.

Although most policymakers appear to favour more secure land rights, they are still searching for complementary measures that will not cancel all of the pro-equity benefits of the current land management regime. By law, land in rural areas is owned collectively by the village (about 300 households) or small group (cunmin xiaozu, with 15-30 households) and is contracted to households (Brandt et al. 2002). One of the most important changes in recent years has been the extension of the duration of the use contract from 15 to 30 years. By 2000, about 98 per cent of villages had amended their contracts with farmers to reflect the longer use rights.

With the issue of use rights resolved, the government is now searching for a mechanism that will permit the remaining full-time farmers to gain access to additional cultivated land and increase their income and competitiveness. One of the main efforts revolves around the development of a new Rural Land Contract Law. The Standing Committee of the National People's Congress has drafted a law and the congress is expected to approve it in the near future. According to this law, although the ownership rights of land will remain with the collective, almost all other rights that would have been held under a private property system are given to the contract holder. In particular, the law clarifies the rights for transfer and exchange of the contracted landsomething that could be taking effect already, as researchers are finding that increasing areas of land in China are rented. The new legislation also allows farmers to use contracted land for collateral to secure commercial loans and allows family members to inherit land during the contracted period. The goal of this new set of policies is to encourage farmers to increase their farm and household short and long-run productivity. 


\section{Farm organisations}

The other major attempt to increase farm productivity and agricultural competitiveness under trade liberalisation is to promote the development of farmer organisations. At one time, the creation of such organisations was a politically sensitive issue. Leaders were concerned about the rise of any organisation outside the government's authority. Such restrictions, however, caused a dilemma in reforming the nation's agricultural and rural economies. Policymakers are also aware that given the small scale of China's farms there are many increases in economic efficiency that might be achieved by the creation of effective rural organisations and that if they are successful in raising incomes, there might be an increase in political stability. The government has now given its support to self-organised farmer groups that focus on agricultural technology and marketing. The Farmers' Professional Cooperative Law was issued in October 2006 to facilitate the development of farmers organisations.

\section{Export subsidies and agricultural support policies}

In one of its most fundamental concessions (since most countries are not required to do so on the basis of their own WTO protocols), China agreed to phase out its export subsidies in the first year of WTO accession. Such subsidies have played a considerable role in assisting the export of maize, cotton and other agricultural products, and in this way have indirectly supported domestic prices. In fact, after phasing out export subsidies, several of China's agricultural sectors (for example, maize and cotton) are likely to be subject to intensive competition from imports.

Besides the elimination of export subsidies, the WTO accession commitments place strict controls on the types and amounts of certain investments. In particular, domestic support to agriculture is divided into 'Green Box' and 'Amber Box' support. As is the case with other WTO members, China faces no limitations on the amount of support classified as Green Box that it can give, but it faces carefully circumscribed rules regarding the amount of support that can be given to activities classified as Amber Box. WTO commitments will, therefore, most likely force China to shift the level and composition of its agricultural support in the future. 
On Amber Box policies, the accession protocol allows a de minimis level of support equal to 8.5 per cent of agricultural gross value product. After intense negotiations, the level was set somewhat below that enjoyed by other developing countries ( 10 per cent) but above that allowed to industrialised countries (5 per cent). Moreover, the list of items used in the computation of China's Amber Box support is wider than that applied to other countries (for example, certain agricultural output and input subsidies for poor farmers that are considered as Green Box in developing countries are included in the computation of Amber Box in China). On paper, therefore, China's hands appear to be quite firmly tied regarding the scope of the support it is able to provide. When one considers the amount of fiscal funds that China has historically devoted to these areas, however, it could be that the de minimis limit will not be binding. The biggest impact could be some time in the future after China has grown further and its budget constraint has been relaxed somewhat. China's commitment should, however, be thought of as fairly limiting as it closes off options for supporting its rural activities in ways that its neighbours in East Asia have done (Martin 2002).

New agricultural and rural development policies

Since the early 2000s, China's leaders have been considering solutions to the 'Three Nongs' issues, which are at the top of the economic development agenda: agriculture, rural areas and farmers. To facilitate economic development in these areas, the government has issued four Number One Documents since 2004. Each of these policy documents was decreed on the first day of the year (the order in which policy documents are issued normally reflects the importance of the policy).

Each of these documents had a specific focus on agricultural and rural development. The 2004 document was aimed primarily at raising farmers' incomes through reducing and eliminating agricultural taxes and fees paid by farmers, increasing income transfer to farmers-particularly those in the western regions-promoting agricultural structural changes and facilitating farmers' off-farm employment. The 2005 document called for substantial increases in agricultural production capacity through massive government investment in technology, land, water and agricultural and 
rural infrastructure. A new rural development strategy-a new socialist countryside development-was the focus of the 2006 Number One Document.

The highlight of the 2007 document was nation-wide abolition of all agricultural taxes, a plan for increasing investment in agricultural and rural development in the eleventh Five-Year Plan period and a commitment to poverty alleviation and other issues such as rural education, sanitation, healthcare, cultural development and community participation. The 2007 document emphasised the critical importance of modern agricultural techniques to the new socialist countryside development.

\section{Conclusions}

In this chapter, we have attempted to meet three objectives. First, we briefly reviewed China's existing agricultural policy, the past performance of China's agriculture and how it changed during the 20 years of reform before China's WTO accession. Next, we examined the main features of the agreement that China committed to in order to join the WTO. Finally, we briefly reviewed the policy changes since China joined the WTO.

We believe that one of the most important messages from this chapter is that, contrary to some opinions, China has begun to adjust to a post-accession environment. Tariffs have been reduced, many laws have been amended, public investment portfolios shifted and policy strategies changed to help China meet its commitments and assist its farmers to take on new roles. That is not to say that the job is over-far from it. The strides that the government has taken so far show that it understands the role it must play as a member of the WTO and that it is committed to living up to its obligations.

Most fundamentally, the government's response to WTO accession involves an entire paradigm shift: from direct participation in the economy to taking on a more indirect regulatory and fostering role. The government has to establish institutions that allow it to create and manage public goods. It needs to regulate markets to correct for market failures. It needs to do the things that the private sector is not willing to do and to do those things that will enhance the productivity of the nation's economic actors. It also needs to move away from an attitude that China's producers need to produce everything and establish an environment that foreign firms will 
be willing to invest in and into which they are willing to bring their best technology and management practices.

Another finding of importance is China's commitment to agricultural and rural development. China has made agricultural and rural development a top priority in the process of modernising its economy. Investment in agricultural and rural development has increased substantially since China joined the WTO in 2001 and can be expected to grow in coming years.

\section{References}

Anderson, K., Huang, J. and lanchovichina, E., 2004. 'Will China's WTO accession worsen farm household income?', China Economic Review, 15:443-56.

Brandt, L., Huang, J. Li, G. and Rozelle, S., 2002. Land rights in China: facts, fictions and issues', The China Journal, 47:67-97.

Cai, F., Wang, D. and Du, Y., 2002. 'Regional disparity and economic growth in China: the impact of labor market distortions', China Economic Review, 11:197-212.

Carter, C.A. and Estrin, A., 2001. China's trade integration and impacts on factor markets, January, University of California, Davis (unpublished).

Colby, H., 2001. Agricultural trade and investment liberalization after China's accession to WTO, OECD Working Paper, Paris.

de Brauw, A., Huang, J. and Rozelle, S., 2000. 'Responsiveness, flexibility and market liberalization in China's agriculture', American Journal of Agricultural Economics, 82(December):1,133-39.

de Brauw, A., Huang, J., Rozelle, S., Zhang, L. and Zhang, Y., 2002. 'China's rural labor markets', The China Business Review, March-April 2002:2-8.

Fan, S., 1991. 'Effects of technological change and institutional reform on production growth in Chinese agriculture', American Journal of Agricultural Economy, 73:266-75.

Fan, S. and Pardey, P., 1997. 'Research productivity and output growth in Chinese agriculture', Journal of Development Economics, 53:115-37. Huang, J. and Bouis, H., 1996. Structural changes in demand for food in Asia, Food, Agriculture and the Environment Discussion Paper, International Food Policy Research Institute, Washington, DC. 
Huang, J. and Chen, C., 1999. Effects of Trade Liberalization on Agriculture in China: institutional and structural aspects, United Nations ESCAP CGPRT Centre, Bogor.

Huang, J. and Rozelle, S., 1996. 'Technological change: rediscovery of the engine of productivity growth in China's rural economy', Journal of Development Economics, 49(2):337-69.

Huang, J., Hu, R. and Rozelle, S., 2003. Agricultural Research Investment in China: challenges and prospects, China's Finance and Economy Press, Beijing.

Huang, J., Rozelle, S. and Chang, M., 2004. 'Tracking distortions in agriculture: China and its accession to the World Trade Organization', World Bank Economic Review, 18(1):59-84.

Huang, J., Rozelle, S. and Pray, C., 2002. 'Enhancing the crops to feed the poor', Nature, 418:678-84.

Huang, J., Rozelle, S. and Wang, H., 2006. 'Fostering or stripping rural China: modernizing agriculture and rural to urban capital flows', The Developing Economies, XLIV-1(March):1-26.

Huang, J., Yang, J. and Rozelle, S., 2007. 'When dragons and kangaroos trade: China's rapid economic growth and its implications for China and Australia', Farm Policy Journal, 4(1):35-49.

Jin, S., Huang, J., Hu, R. and Rozelle, S., 2002. 'The creation and spread of technology and total factor productivity in China's agriculture', American Journal of Agricultural Economics, 84(4):916-39.

Lardy, N.R., 1995. 'The role of foreign trade and investment in China's economic transition', China Quarterly, 144:1065-82.

Li, S., Zhai, F. and Wang, Z., 1999. The global and domestic impact of China joining the World Trade Organization, Project Report, Development Research Center, The State Council, Beijing.

Lin, J.Y., 1991. 'Prohibitions of factor market exchanges and technological choice in Chinese agriculture', Journal of Development Studies, 27(4):1-15.

--, 1992. 'Rural reforms and agricultural growth in China', American Economic Review, 82:34-51.

Lohmar, B., 1999. Rural institutions and labor movement in China, PhD thesis, Department of Agricultural Economics, University of California, Davis. Martin, W., 2002. 'Implication of reform and WTO accession for China's agricultural policies', Economies in Transition, 9(3):717-42. 
McMillan, J., Walley, J. and Zhu, L., 1989. 'The impact of China's economic reforms on agricultural productivity growth', Journal of Political Economy, 97:781-807.

Ministry of Agriculture, 1985-2005 (various issues). China's Agricultural Yearbook, China Agricultural Press, Beijing.

National Bureau of Statistics of China (NBSC), various issues (1985-2006).

China Statistical Yearbook, China Statistics Press, Beijing.

--, various issues. China Rural Statistical Yearbook, China Statistics Press, Beijing.

Nyberg, A. and Rozelle, S., 1999. Accelerating China's Rural Transformation, World Bank, Washington, DC.

Rosen, D.H., Rozelle, S. and Huang, J., 2004. Roots of Competitiveness:

China's Evolving Agriculture Interests, Institute for International Economics, Washington, DC.

Rozelle, S. and Huang, J., 2001. Impacts of trade and investment liberalization policy on China's rural economy, OECD Working Paper, Organisation for Economic Co-operation and Development, Paris.

Rozelle, S., Park, A., Huang, J. and Jin, H., 2000. 'Bureaucrat to entrepreneur: the changing role of the State in China's transitional commodity economy', Economic Development and Cultural Change, 48(2):227-52.

Sonntag, B.H., Huang, J., Rozelle, S. and Skerritt, J.H., 2005. China's Agricultural and Rural Development in the Early 21st Century, Australian Centre for International Agricultural Research, Canberra.

van Tongeren, F. and Huang, J., 2004. China's food economy in the early 21st century, Report No.6.04.04, Agricultural Economics Research Institute (LEI), The Hague.

Wang, J., 2000. Property right innovation, technical efficiency and groundwater management: case study of groundwater irrigation system in Hebei, China, $\mathrm{PhD}$ thesis, Chinese Academy of Agricultural Sciences, Beijing.

Wang, J., Huang, J., Huang, Q. and Rozelle, S., 2006. 'Privatization of tube wells in North China: determinants and impacts on irrigated area, productivity and the water table', Hydrogeology Journal, 14(3): 275-85.

World Bank, 2002. World Development Indicators 2002, World Bank, Washington, DC.

World Trade Organization (WTO), 2001. China's WTO Protocol of Accession, November, World Trade Organization, Geneva. 